UDC 378.013.43:81'243

DOI: https://doi.org/10.32820/2074-8922-2020-68-7-13

\author{
FORMATION MODEL OF THE STUDENTS INTERCULTURAL SKILLS \\ ON THE BASIS OF THE COMMUNICATIVE ETHNOGRAPHIC APPROACH \\ AT STUDING OF FOREIGN LANGUAGE. \\ (C) Vyktoryia Vemian \\ Ukrainian engineering - pedagogics academy
}

\author{
Information about the Author \\ Vyktoryia Vemian: ORCID: 0000-0002-1822-9343, vemian@uipa.edu.ua; assistant of Foreign languages \\ Department of the Ukrainian Engineering Pedagogics Academy,16 Universitetskaya Str. 61003, Kharkiv, Ukraine
}

The article gives the definition of the communicative-ethnographic approach which is aimed at the formation of foreign language communicative competence.The author explores available theoretical developments in the area of intercultural competence of the students in the conditions of immersion in the authentic and socio-cultural environment. However, it is necessary to state about existence of a number has not yet developed and insufficiently studied questions of this aspect.

As a rule, some aspects of introducing intercultural competence into the educational process are examined from the technical, technological and didactic view. Special attention is given to the topics that are directly included in the educational process or supporting its tasks, whose effectiveness can be increased. In addition, the several ways to implement this approach are proposed based on the development of intercultural skills.

On the one hand. It is determined the range of the students intercultural skills developed on the basis of a communicative-ethnographic approach; It is established the psychological and pedagogical conditions for the development of the students intercultural skills on the basis of the communicative-ethnographic approach. On the other hand, a model for the development of intercultural skills of students has been developed on the basis of a communicative- ethnographic approach; Communicative and ethnographic approach is one of the modern cultural approaches aimed at the formation of foreign language communicative competence and intercultural competence which are studied in terms of immersion in an authentic linguistic and socio-cultural environment. The author describes linguodidactic characteristics in the communicative-ethnographic approach.

The methodology for the development of the students intercultural skills on the basis of the communicative-ethnographic approach is substantiated in order to determine the effectiveness of the methodology for the development of the students intercultural skills on the basis of the communicativeethnographic approach.

Keywords: communicative-ethnographic approach, formation of foreign language communicative competence, intercultural competence, immersion, authentic and socio-cultural environment, development of intercultural skills

Вем’ян B. $\boldsymbol{\Gamma}$. «Модель формування міжкультурних умінь студентів на основі комунікативноетнографічного підходу при вивченні іноземної мови »

У статті дано визначення комунікативно-етнографічного підходу, спрямованого на формування іншомовної комунікативної компетентності. Автор досліджує наявні теоретичні розробки в галузі міжкультурної компетентності студентів в умовах занурення в автентичне та соціокультурне середовище. Однак необхідно констатувати існування ряду ще не розроблених і недостатньо вивчених питань цього аспекту.

Як правило, деякі аспекти впровадження міжкультурної компетентності в навчальний процес розглядаються з технічного, технологічного та дидактичного погляду. Особлива увага приділяється темам, які безпосередньо включаються в освітній процес або підтримують його завдання, ефективність яких може бути підвищена. Крім того, пропонується кілька способів реалізації цього підходу, заснованому на розвитку міжкультурних навичок.

3 одного боку. визначено коло студентських міжкультурних навичок, вироблених на основі комунікативно-етнографічного підходу. Встановлено психолого-педагогічні умови для розвитку у студентів міжкультурних навичок на основі комунікативно-етнографічного підходу. 3 іншого боку, модель розвитку міжкультурних навичок студентів розроблена на основі комунікативно- 
етнографічного підходу. Комунікативно-етнографічний підхід - один із сучасних культурних підходів, спрямованих на формування іншомовної комунікативної компетентності та міжкультурної компетентності, які вивчаються в умовах занурення в автентичному мовному та соціокультурному середовище. Автор описує лінгводидактичні характеристики в комунікативно-етнографічному підході.

Обгрунтовано методологію розвитку міжкультурних навичок студентів на основі комунікативно-етнографічного підходу з метою визначення ефективності методології розвитку міжкультурних навичок студентів на основі комунікативно-етнографічного підходу;

Вемьян $\boldsymbol{B} . \boldsymbol{\Gamma}$. «Модель формирования межкультурных умений студентов на основе коммуникативно-этнографического подхода при изучении иностранного языка»

В статье дается определение коммуникативно-этнографического подхода, направленного на формирование иноязычной коммуникативной компетенции. Автор исследует имеющиеся теоретические разработки в области межкультурной компетенции студентов в условиях погружения в аутентичную и социокультурную. среду. В настоящее время необходимо констатировать наличие ряда еще не разработанных и недостаточно изученных вопросов этого аспекта.

Как правило, некоторые аспекты внедрения межкультурной компетенции в образовательный процесс рассматриваются с технической, технологической и дидактической точек зрения. Особое внимание уделяется темам, которые непосредственно входят в образовательный процесс или поддерживают его задачи, эффективность которых может быть повышена. Кроме того, предлагается несколько способов реализации этого подхода, основанных на развитии межкультурных навыков.

С одной стороны, определен спектр межкультурных умений студентов, развиваемых на основе коммуникативно-этнографического подхода. На основе коммуникативно-этнографического подхода созданы психолого-педагогические условия развития у студентов межкультурных навыков. С другой стороны, модель развития межкультурных навыков студентов была разработана на основе коммуникативно-этнографического подхода. Коммуникативно-этнографический подход - один из современных культурных подходов, направленных на формирование иноязычной коммуникативной компетенции и межкультурной компетенции, которые изучаются в условиях погружения в аутентичную языковую и социокультурную среду. Автор описывает лингводидактические характеристики в коммуникативно-этнографическом подходе.

Обоснована методика развития межкультурных навыков студентов на основе коммуникативноэтнографического подхода с целью определения эффективности методики развития межкультурных навыков студентов на основе коммуникативно-этнографического подхода;

Ключевые слова: коммуникативно-этнографический подход, формирование иноязычной коммуникативной компетенции, межкультурная компетенция, погружение, аутентичная языковая и социокультурная среда, развитие межкультурных навыков.

Formulation of the problem. In modern conditions, the educational standards of higher education fully reflect the social order of society to train professionals who speak a foreign language for intercultural communication. The competency approach allowed to focus attention on learning outcomes which is reflected in terms of general cultural, general professional and professional competencies. As a result of the studies, students must form a number of competencies that allow them to be guided by the principles of cultural relativism and ethical norms, which provide for the rejection of ethnocentrism and respect for the uniqueness of foreign culture and values of foreign society; possession of intercultural communication skills that ensure the adequacy of social and professional contacts.

At this moment, a number of approaches are being implemented in language education in
Ukraine which together contribute to the formation of foreign language communicative and intercultural competence of students, thereby creating conditions for preparing students for intercultural interaction with representatives of the different countries and cultures. Expansion of international relations in various fields of activity allows a large number of the students of higher educational institutions to regularly travel abroad. Immersion into the authentic linguistic and cultural environment, as well as into the environment of intercultural contacts with representatives of different countries and cultures in the foreign language being studied has great didactic potential. This, on the one hand, allows students to continue their foreign language and socio-cultural education in immersion conditions, and on the other hand, it creates the additional opportunities for the development of their intercultural skills. 
The purpose of the work. The research problem stems from the above contradictions: what is the methodology for the development of intercultural skills of students on the basis of a communicative and ethnographic approach. In this regard, the relevance of this article is the methodology for the development of intercultural skills of students on the basis of a communicativeethnographic approach. This is especially true for teaching foreign languages to students using a professional orientation where the main object is linguistic communication. This approach requires the teacher to adjust the teaching methodology when speech is already being studied as a means of influencing one person on another in the process of communicative activity [1, p.18-20].

Analysis of recent research and publications. At the moment, there is a fairly large amount of researches devoted to preparing students for intercultural communication by means of a foreign language. The study of scientific literature indicates that the focus of the researchers' work was the following issues:

- studying the cognitive aspects of cultural ownership and the formation of intercultural competence of students environment are analyzed in the works of (H. H. Almazova, 2003; P. Sysoev, 2003);

- development of the methods for forming aspects of socio-cultural competence (O. A Bondarenko, 2000; A. A Maksayev, 2015);

- development of the socio-cultural component of the content of foreign language teaching in secondary school and university (V. V. Safonova, P. V. Sysoev, 2004, 2007; S.A. Strokova, 2002);

- development of methods of teaching a foreign language in terms of immersion in the authentic linguistic and cultural environment (P. V. Sysoev, 2014).

As a result, it can be argued that there is a strong scientific basis for considering the problem of the developing intercultural skills of the students in terms of immersion in the language and cultural environment on the basis of communicative and ethnographic approach. At the same time, we have to admit the presence of a number of not yet developed and insufficiently studied issues which include the following:

1) the linguodidactic characteristics of the communicative-ethnographic approach for teaching a foreign language and culture have not been determined;

2) the nomenclature of the students intercultural skills is not defined which developing on the basis of a communicative-ethnographic approach;
3) the psychological and pedagogical conditions for the development of the students intercultural skills on the basis of the communicative and ethnographic approach have not been identified;

4) a model for the development of the students intercultural skils on the basis of a communicative and ethnographic approach has not been developed;

5) the technology for the development of the students intercultural skills has not been developed on the basis of a communicativeethnographic approach.

Thus, there are contradictions between the social need of graduates of higher educational institutions for the formation of foreign language communicative and intercultural competencies which allow them to interact with the representatives of the different countries and cultures on the basis of the principles of ethnorelativism and impartiality and the limited opportunities for teaching of the students intercultural interaction in the foreign language classes; between the linguodidactic potential of the communicative and ethnographic approach to teaching foreign language intercultural interaction and the lack of methods for using, this approach in practice during the immersion of students in an authentic language and cultural environment.

\section{Presentation of the main research} material. The communicative-ethnographic approach is one of the cultural studies approaches aimed at the formation of foreign language communicative competence and intercultural competence of the students in the conditions of immersion in the authentic linguistic and sociocultural environment. Its main linguodidactic characteristics include the following:

1) the approach is implemented in terms of immersion in an authentic linguistic and cultural environment;

2) the approach is implemented in a single system along with competency, personality-activity, communicative-cognitive, socio-cultural and multicultural approaches to learning a foreign language and culture;

3) approach aimed at the forming of all components of foreign language communicative competence of the students;

4) the approach is aimed at the formation of intercultural competence of students; the methodological dominant is three methods of ethnography (questionnaires, interviews, observations) and problematic cultural tasks which are studied within this approach and act as the ethnographers who observe, record, analyze 
and interpret the facts and realities of the culture of the studied language.

The ethnographic component of this approach focuses on one of the important conditions for teaching a foreign language and the culture of the country of English language, namely that the students should be directly in the linguistic and sociocultural environment, studying and observing the communicative behavior of native speakers. In contrast to the sociocultural approach in which learning is viewed in the context of a dialogue of cultures and is aimed at comparative study of foreign and native cultures and the intercultural approach in which training is aimed at preparing the student for the effective implementation of intercultural communication, the communicative-ethnographic approach involves the direct immersion in an authentic language environment and establishing contacts with its representatives. The important fact is that the essence of the communicative-ethnographic approach is to study the everyday and cultural life of peoples living in the same territory, which contributes to the formation of adequate ideas about polyculturalism as a norm of coexistence of cultures [6].

Based on the communicative-ethnographic approach, it is possible to develop the following intercultural skills of the students: to initiate the intercultural contact; to support the intercultural interaction in the context of intercultural dialogue (maintaining a favorable atmosphere of communication, leveling cultural conflicts); to identify the situations/areas of the cultural differences and possible cultural conflicts; to avoid or get out of the situations of cultural conflicts; to act as a cultural mediator who represents his culture as well as understands and respects the values of the representatives of the contacting cultures; to interpret the cultural facts and realities from the standpoint of the value system of such cultures, to avoid the ethnocentric judgments; to show respect for the representatives of the contacting culture. The development of intercultural skills of the students on the basis of communicative-ethnographic approach will be successful by taking into account the following psychological and pedagogical conditions: motivation of students to develop intercultural skills in the conditions of immersion; immersion in an authentic cultural and linguistic environment; use of problematic tasks and methods of ethnography in teaching; compliance with the algorithm of actions in the implementation of ethnographic methods. The model of intercultural skills development for the students on the basis of communicativeethnographic approach consists of four interconnected blocks: target, theoretical, technological and evaluation-effective ones [4, p.183]. Despite the fact that the implementation of the communicativeethnographic approach in practice is carried out in interaction with other approaches, thereby creating conditions for the continuation of language and socio-cultural education in the conditions of immersion in an authentic linguistic and socio-cultural environment.. This model is based on a combination of the following approaches: systemic, competence, personalactivity, communicative-cognitive, socio-cultural and communicative-ethnographic. In practice, these approaches are implemented by taking into account the general didactic principles (awareness, activity, accessibility, individualization) and methodological principles (communicative orientation of learning, situational and thematic organization of learning, novelty, dialogue of cultures, didactic cultural similarity, dominance of problematic cultural tasks, cultural reflection and cultural variability.

The method of the developing students' intercultural skills in the conditions of immersion in an authentic linguistic and sociocultural environment based on communicativeethnographic approach includes five stages (preparatory, research, analytical, product creation and evaluation) by using three methods of ethnography (observation, questionnaires and interviews) and complex of problem tasks [3, p.19]. A special role in the development is to determine the linguodidactic characteristics of the communicative-ethnographic approach to teaching a foreign language and culture in the conditions of immersion; determining the nomenclature of the students intercultural skills developing on the basis of the communicative and ethnographic approach; identification and substantiated psychological and pedagogical conditions for the development of intercultural skills of the students on the basis of communicative and ethnographic approach; development of a model and technology for the development of students' intercultural skills based on a communicative and ethnographic approach.

Communicative and ethnographic approach is one of the modern cultural approaches aimed at the formation of foreign language communicative competence and intercultural competence which are studied in terms of immersion in an authentic 
linguistic and socio-cultural environment. It is implemented in close connection with the systemic, competence, communicative-cognitive, socio-cultural and multicultural approaches allowing those [2] who are learning to continue foreign language education in the process of educational internships in the countries of the studied language. The communicativeethnographic approach has a number of linguodidactic characteristics:

1) The approach is implemented in terms of immersion in an authentic linguistic and cultural environment - communicative and ethnographic approach is one of the modern cultural approaches to teaching a foreign language and culture of the country of the studied language which is implemented by immersing students in an authentic language and socio-cultural environment;

2) The communicative-ethnographic approach is implemented in a single system side by side with competence, personality-activity, communicative-cognitive, socio-cultural and multicultural approaches to learning a foreign language and culture - communicative and ethnographic approach is aimed at further formation of foreign language communicative competencies in terms of immersion in an authentic linguistic and cultural environment. In isolation, this approach does not allow the students to form all the components of foreign language communicative competence and intercultural competence. However, its inclusion in the system of existing approaches to learning foreign language and culture will be able to significantly enrich the language and socio-cultural practice of students, developing those linguistic, social and intercultural skills that are difficult to develop by immersion;

3) The approach aimed at the formation of all components foreign language communicative competencies of students - the implementation of this approach requires students who speak a foreign language at the level of $\mathrm{B} 1$ and above. This level will allow students to: prepare materials for interviews, observations and questionnaires and use each of the three methods of ethnography in practice, communicating in the language being studied and discuss and interpret the results\$

4) An approach aimed at forming students' intercultural competence - this approach will create the exceptional conditions for the development of the students intercultural skills. Unlike other existing approaches, the communicative-ethnographic approach focuses on foreign language interaction with representatives of the country whose language is being studied, through intercultural interaction, can develop intercultural skills that can be transferred to other situations of communication with representatives of others countries and cultures regardless of their native language;

5) The methodological dominant is three methods of ethnography (interviews, observation, questionnaires) and problematic cultural tasks the approach will achieve the real results when using the relevant problem cultural tasks at the stages of preparation of interviews, observations and questionnaires as well as at the stage of processing the data, their classification, generalization and discussion. The main element of the method of implementation of the communicative-ethnographic approach is three methods of ethnography: (interviews, observations, questionnaires) which allows to organize the intercultural interaction with representatives of the country whose language and culture is being studied;

6) Students perform in the role of the ethnographers who observe, record, analyze and interpret the facts and realities of the culture of the country of the target language - in this approach, students act as ethnographers. With the help of teachers, they first prepare material for observation, interviews or questionnaires, then collect the cultural material using three methods of ethnography, and then classify, summarize, analyze, discuss the data obtained and draw the appropriate conclusions

The communicative-ethnographic approach creates the didactic conditions for the development of the students intercultural skills - the ability and willingness to interact with the representatives of other cultures while realizing their own cultural affiliation. Based on the analysis and generalization of a number of methodological works devoted to the component composition of intercultural competence, we can determine the nomenclature of the students intercultural skills developing in immersion conditions on the basis of a communicative-ethnographic approach [5, p.109]. Taking into account the fact that foreign language communicative competence and intercultural competence are closely interrelated. In addition, it is possible to learn intercultural interaction exclusively on the socio-cultural component of the educational content.

Consider some main methods ethnography which include observation, polling, questionnaires, interviews. The observation method is considered one of the most effective methods of ethnography in which the student 
immersed insocio-cultural environment of the country where the language is spoken, observes the communicative behavior of representatives of a different linguistic society, systematizes the received information and analyzes it and draws conclusions. It should be noted that this method of ethnography allows fixation on the several objects of observation according to the different parameters (observation of verbal and non-verbal behavior). However, it is necessary to dwell on the minor disadvantages of this method. First, the possibility of deviation is great from the purpose of observing and receiving false information, and secondly, obtained earlier experience has a significant impact on subsequent observation facts.

For communication we offer the following projects for observation:

1. Communication between the seller and the buyer in the store;

2. Order and ride in a taxi;

3. Purchasing ticket at the railway ticket office;

4. Ordering food in a restaurant;

5. Check in to the hotel.

Questioning as a method of ethnography in which the researcher prepares a survey of respondents in advance on the most relevant aspects of linguistic and cultural reality. For this purpose, a questionnaire is being prepared with questions, a survey is being conducted and the results of the survey are analyzed, classification, systematization and interpretation of the data obtained. The types of questionnaires vary depending on a number of characteristics: the number of respondents (individual, group, mass), the completeness of coverage (continuous, selective), the type of contacts with respondents (full-time, correspondence).

For example we offer a number of questions:

1.Do you use the services of an online bank? yes, no.

2. What brand car do you use? Toyota Honda Subaru.

3. What sources are you looking for job vacancies? Your own answer.

The survey is conducted with the aim of collecting primary information for its subsequent processing: analysis, generalization, classification and interpretation. Initially it is created a list of the topical questions on a specific topic However, the questions should be short, specific and logical. You should also exclude from the questions the use of little-known words and special terms that can cause difficulties in answering.
For students - Academic survey templates. They are one of the best ways to understand how students and their parents respond to the efforts taken by your education institution. A questionnaire designed by industry experts helps to assess the parent/student feedback on a course evaluation, curriculum planning, training sessions, etc.

The interview is the most difficult method of ethnography and the interpersonal dialogue with representatives of another linguistic culture. Lke a survey, an interview requires the preparation of the questions but the wording can be made more detailed [7]. After the interview, the researcher analyzes and formulates conclusions. Depending on the objectives of the study and the stage of its course, interviews are divided into preliminary (initial research stage), main (collection of basic information) and control (verification of results). The designated ethnographic methods can be used by researchers at any stage of training. However, the choice of the particular method depends both on the language training of the students and on the willingness to satisfy their cognitive and research needs.

The advantages of this method indicate that, despite the statistical significance in the development of all intercultural skills that the students develop in the course of ethnographic research, the development of skills takes place in different ways and with different initial levels. Analysis of the results shows that a number of students' skills have already been developed at a sufficiently high level. In particular, the students expressed the opinion that they were able to make intercultural contact, act as a cultural mediator representing their culture and also understanding and respecting values and showing respect for the representatives of other cultures. Such indicators can be explained by the fact that intercultural skills are very closely intertwined with foreign language communication (language) skills which are traditionally developed in the students at the levels of foreign language proficiency A2-B2. To initiate intercultural contact, many students know how to start a conversation using language formulas for greeting, conversation support, questioning, etc. Students also learned for years to act as cultural mediators when, after studying any aspect of the culture of the country of the target language, they were asked to reflect on their native culture or country and, by analogy, talk about how a particular cultural aspect is represented in Ukraine.

According to the questionnaire, such skills include: supporting intercultural interaction in the context of intercultural dialogue (maintaining a 
favorable atmosphere of communication, leveling cultural conflicts and interpreting cultural facts and realities from the standpoint of cultural values, avoiding ethnocentric judgments. This once again testifies to the inextricable connection between intercultural competence and foreign language communicative competence in the real communication and interaction with representatives of different countries and cultures.

The last two intercultural skills - identifying situations in the field of cultural differences and possible cultural conflicts and avoiding or getting out of the situations of cultural conflicts - caused the greatest difficulties for students who showed incompetent possession of these skills. Such results are explained by the fact that students in higher education institutions are purposefully not taught to identify the areas of cultural differences or conflicts, as well as how to avoid or get out of conflicts. And still, the indicators of the development of these skills are still low enough to talk about preparing students for such actions.

\section{Список використаних джерел}

1. Артеменко Т. М. Про деякі ефективні стратегії оптимізації процесу викладання іноземних мов / Артеменко Т. М., Липко І. П. // Викладання мов у вищих навчальних закладах освіти на сучасному етапі. Міжпредметні зв'язки. Наукові дослідження. Досвід. Пошуки. 2010. - Вип. 16. C. 10-18.

2. Кузьмінський А. І. Педагогіка : підручник / А. І. Кузьмінський, В. Л. Омеляненко. - Київ : Знання Прес, 2008. - 447 с.

3. Лавриненко О. Л. Структурнофункціональні особливості мовної особистості студентів : автореф. дис. ... канд. психол. наук / О. Л. Лавриненко ; Волин. нац. ун-т ім. Лесі Українки. - Луцьк, 2011. - 19 с.

4. Манакін В. М. Мова i міжкультурна комунікація / В. М Манакін. - Київ : ЦУЛ, 2012. $288 \mathrm{c}$.

5. М'язова І. Ю. Особливості тлумачення поняття «міжкультурна комунікація» / I. Ю. М'язова // Філософські проблеми гуманітарних наук. - 2006. - № 8. - С. 108-113.

6. Сысоев П. В. Языковое поликультурное образование в XXI в. / П. В. Сысоев // Язык и культура. - 2009. - № 2. С. 96-110.

7. Meho L. I. E-mail interviewing in qualitative research: a methodological discussion / L. I. Meho // Journal of the American Society for Information Science and Technology. - 2006. - № 57. Pp. 1284-1295 p.
In general, it can be stated that the participation of students in training aimed at developing their intercultural skills on the basis of a communicative ethnographic approach allows achieving the desired result.

Conclusions from this study. In conclusion, we summarize the results, the proposed hypothesis is confirmed by the achievements of the tasks, the results are described and the conclusion is formulated that the communicative-ethnographic approach is one of the cultural approaches aimed at the formation of foreign language communicative competence and intercultural competence of students in conditions of immersion in an authentic language and socio-cultural environment.

The prospect of the research lies in the further development of the problem of using the communicative-ethnographic approach in the conditions of immersion in an authentic linguistic and socio-cultural environment while teaching a foreign language.

\section{References}

1. Artemenko, TM \& Lypko, IP 2010, 'Pro deiaki efektyvni stratehii optymizatsii protsesu vykladannia inozemnykh mov'[About some effective strategies for optimizing the process of teaching foreign languages], Vykladannia mov $u$ vyshchykh navchalnykh zakladakh osvity na suchasnomu etapi. Mizhpredmetni zviazky. Naukovi doslidzhennia. Dosvid. Poshuky, iss. 16, pp. 10-18.

2. Kuzminskyi, AI \& Omelianenko, VL 2008, Pedahohika, [Pedagogy] Znannia Pres, Kyiv.

3. Lavrynenko, OL 2011, 'Strukturnofunktsionalni osoblyvosti movnoi osobystosti studentiv'[Structural and functional features of students' language personality], Kand.psykhol.n. abstract, Volynkyi natsionalnyi univertytet imeni Lesi Ukrainky, Lutsk.

4. Manakin, VM 2012, Mova i mizhkulturna komunikatsiia, [Language and intercultural communication] Tsentr navchalnoi literatury, Kyiv.

5. Miazova, IYu 2006, 'Osoblyvosti tlumachennia poniattia mizhkulturna komunikatsiia'[Features of interpretation of the concept of "intercultural communication"], Filosofski problemy humanitarnykh nauk, no. 8, pp. 108-113.

6. Sysoev, PV 2009, 'Jazykovoe polikulturnoe obrazovanie v XXI veke'[Language multicultural education in the XXI century], Jazyk $i$ kultura, no. 2, pp. 96-110.

7. Meho, LI 2006, 'E-mail interviewing in qualitative research: a methodological discussion', Journal of the American Society for Information Science and Technology, no. 57, pp. 1284-1295.

The article was received 25 July 2020 